\title{
A Single Case Study of Treating H-Pyroli Infection with Coconut Oil
}

\author{
Case Report
}

\section{Anagha $\mathbf{U}^{*}$, Binitha $\mathrm{A}^{2}$}

\author{
1. PG Scholar, 2. Professor, Department of Panchakarma, \\ VPSV Ayurveda College, Kottakkal, Kerala, India
}

\begin{abstract}
Helicobacter pylori (H-Pylori) are a Gram negative spiral organism in GI Tract. Final effect of H-pylori on the GI tract is variable and determined by microbial and host factors. The particular end result of H-Pylori varies from chronic gastritis to PUD, Gastric MALT Lymphoma. A case presented with chronic gastritis associated H-Pylori infection. Which showed resemblance with Clinical features of vatha -pitha Parinaamashoola (pain during digestion). It was intervened successfully with samanasnehapana (internal oleation therapy) of coconut oil. Coconut oil administered for 15 days. Helicobacter pylori immunoglobulin (IgG H-pylori) evaluated before and after the treatment. A positive H-pylori infection became negative after the treatment.
\end{abstract}

Key Words: Parinaamashoola, Coconut oil, H-Pylori infection, Samana snehapanam.

\section{Introduction}

H-Pylori infection is virtually always associated with chronic active gastritis. It is found most commonly in the deeper portion of mucus gel. The particular end result of H-Pylori is determined by complex interplay between bacterial and host factors. Infection with $\mathrm{H}$ pylori depends on the bacteria's ability to produce urease. Urease produces ammonia from urea, an essential step in alkalizing the surrounding $\mathrm{pH}(1)$. HPylori makes protease and phospholipase that break down glycoprotein lipid complex of the mucous gel thus reducing the efficacy of this first line mucosa defense. The bacteria produce surface factor that are chemotactic for neutrophils and monocytes which in turn contributes to epithelial cell injury resulting in gastritis(2). The integrity of gastric mucosa is maintained by intricate system that provides mucosal defense and repair. In ayurvedic parlence Kledaka kapha protects the aamasaya (stomach) by virtue of its intrinsic property (3). In the pathogenesis of Parinaamashoola perturbation of kledaka kapha occurred in the first phase and the increased vaata provoke pitta induces shoola (pain) (4). Infection with H-pylori showed similarities with clinical feature of vatha -pitha Parinaamashoola (pain during digestion). The treatment for Parinaamashoola with predominance of two dosha is snehana (oleation therapy) (5). According to susrutha samhitha coconut oil has vatha-pitha shamaka properties (6).

\section{* Corresponding Author:}

\section{Anagha U}

PG Scholar,

Department of Panchakarma,

VPSV Ayurveda College,Kottakkal

Email Id: anaghaedappal@gmail.com

\section{Case Report}

51 year old Muslim married female patient visited OPD of VPSV Ayurveda College, Kottakkal with OP NO. 20180051415 (October, 2018) with presenting complaints of heart burn and epigastric pain. Pain starts within 3 hours of having food and was more pronounced at night.

\section{History of presenting complaint}

Patient was apparently healthy 3 years back; gradually she developed heart burn especially while taking hot and spicy items. Acidic regurgitations were present occasionally. Gaseous abdominal distention and feeling of incomplete bowel evacuation presented along with it. Patient consulted an allopathic physician and took antacids for the same and acidic regurgitation subsided. But most of the symptoms reappeared on discontinuing medicine within few months. She underwent endoscopic examination which revealed antral gastritis, and took modern treatment for 3 months and had very trivial relief. Hence she came to the OPD of Panchakarma department of VPSV Ayurveda College, Kottakkal.

\section{Past history}

Nothing relevant

\section{Personal history}

Patient was on mixed diet with moderate appetite and she was used to take fried spicy items regularly which aggravated the condition. She had disturbed sleep due to pain. Frequency of micturition was regular. Bowel was irregular and unsatisfactory with hard stools. Her menstrual cycles were regular with 4-5 days of bleeding. 


\section{General examination}

Patient showed average built, moderate nutrition with normal vitals. Pulse rate $72 /$ minute, Heart rate $72 /$ minute, respiratory rate $18 /$ minute, blood pressure 130/90 $\mathrm{mmHg}$ and body weight $60 \mathrm{~kg}$

\section{Systemic examination}

Per abdominal examination showed round contour with striae on lower abdomen. There were no dilated veins and pulsations and umbilicus was inverted. On palpation Grade 1 tenderness was noticed on epigastrium.

The symptoms observed were, pain present on aharaparinama kaala (during digeston), adhmaana (abdominal distention), atopa (borborygmus), vit vibandham (constipation), trishna (thirst), daha(burning sensation). Pain aggravates by intake of katu, amla, lavana (hot, spicy, sour, salty items) and sitha dravyas (cold items) were upasaya (favourable). Based on clinical presentation condition was diagnosed as Parinama soola (VP Predominant).

\section{Investigation}

Table 1: Summarizes the IgG H-Pylori before and after treatment

\begin{tabular}{|c|c|c|}
\hline Test & $\begin{array}{c}\text { Before } \\
\text { treatment }\end{array}$ & $\begin{array}{c}\text { After } \\
\text { treatment }\end{array}$ \\
\hline IgG H-Pylori & $16.01 \mathrm{IU} / \mathrm{ml}$ & $6.14 \mathrm{IU} / \mathrm{ml}$ \\
\hline Normal range of IgG $\mathrm{H}$-pylori is $<8 \mathrm{IU} / \mathrm{ml}$
\end{tabular}

\section{Subjective assessment}

Subjective assessment was based on the Gastrointestinal symptom rating scale (GSRS) and is grade as mentioned below:

\section{Gastrointestinal Symptom Rating Scale (GSRS)}

A rating scale for gastrointestinal symptoms in patients with irritable bowel syndrome and peptic ulcer disease. Circle the number which best represents the current severity of the symptom.

\section{Abdominal pains}

Representing subjectively experienced bodily discomfort, aches and pains.

The type of pain may be classified according to the patient's description of the appearance and quality of the pain as epigastric, on the basis of typical location, association with acid-related symptoms, and relief of pain by food or antacids; as colicky when occurring in bouts, usually with a high intensity, and located in the lower abdomen; and as dull when continuous, often for several hours, with moderate intensity. Rate according to intensity, frequency, duration, request for relief, and impact on social performance.
0 - No or transient pain
1 Occasional aches and pains interfering with some social activities Prolonged and troublesome aches and pains
2 - causing requests for relief and interfering with many social activities
3 - Severe or crippling pains with impact on all social activities

\section{Heartburn}

Representing retrosternal discomfort or burning sensations. Rate according to intensity, frequency, duration, and request for relief.
0 - No or transient heartburn
1 - Occasional discomfort of short duration
2 - Frequent episodes of prolonged discomfort;
2 - requests for relief
3 - Continuous discomfort with only transient relief by antacids

\section{Acid regurgitation}

Representing sudden regurgitation of acid gastric content. Rate according to intensity, frequency, and request for relief.

0 - No or transient regurgitation

1 - Occasional troublesome regurgitation

2 - Regurgitation once or twice a day; requests for

2 - relief

3 - Regurgitation several times a day; only transient and insignificant relief by antacids

\section{Sucking sensations in the epigastrium}

Representing a sucking sensation in the epigastriumwith relief by food or antacids. If food or antacids are not available, the sucking sensations progress to ache, and pains. Rate according to intensity, frequency, duration, and request for relief.

0 - No or transient sucking sensation

1 - Occasional discomfort of short duration; no - requests for food or antacids between meals

2 - Frequent episodes of prolonged discomfort, - requests for food and antacids between meals

3 - Continuous discomfort; frequent requests for food or antacids between meals

\section{Nausea and vomiting}

Representing nausea which may increase to vomiting. Rate according to intensity, frequency, and duration.
0 - No nausea
1 - Occasional episodes of short duration
2 - Frequent and prolonged nausea; no vomiting
3 - Continuous nausea; frequent vomiting

\section{Borborygmus}

Representing reports of abdominal rumbling. Rate according to intensity, frequency, duration, and impact on social performance

0 - No or transient borborygmus

1 - Occasional troublesome borborygmus of short duration

Frequent and prolonged episodes which can be

2 - mastered by moving without impairing social performance

3 - Continuous borborygmus severely interfering with social performance

\section{Abdominal distension}

Representing bloating with abdominal gas. Rate according to intensity, frequency, duration, and impact on social performance. 
0 - No or transient distension

1 - Occasional discomfort of short duration

2 - Frequent and prolonged episodes which can be mastered by adjusting the clothing

3 - Continuous discomforts seriously interfering with social performance

\section{Eructation}

Representing reports of belching. Rate according to intensity, frequency, and impact on social performance.

0 - No or transient eructation

1 - Occasional troublesome eructation

2 - Frequent episodes interfering with some social 2 - activities

3 - Frequent episodes seriously interfering with social performance

\section{Increased flatus}

Representing reports of excessive wind. Rate according to intensity, frequency, duration, and impact on social performance

0 - No increased flatus

1 - Occasional discomfort of short duration

2 - Frequent and prolonged episodes interfering

- with some social activities

3 - Frequent episodes seriously interfering with

3 - social performance

\section{Decreased passage of stools}

Representing reported reduced defecation. Rate according to frequency. Distinguish from consistency.

0 - Once a day

1 - Every third day

2 - Every fifth day

3 - Every seventh day or less frequently

\section{Increased passage of stools}

Representing reported increased defecation. Rate according to frequency. Distinguish from consistency.

0 - Once a day

1 - Three times a day

2 - Five times a day

3 - Seven times a day or more frequently

\section{Loose stools}

Representing reported loose stools. Rate according to consistency independent of frequency and feelings of incomplete evacuation.

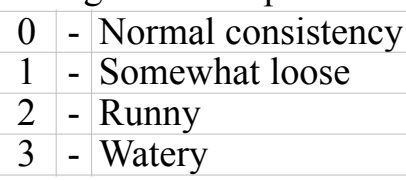

\section{Hard Stools}

Representing reported hard stools. Rate according to consistency independent of frequency and feelings of incomplete evacuation.
0 - Normal consistency
1 - Somewhat hard

\section{2 - Hard}

3 - Hard and fragmented, sometimes in combination with diarrhea

\section{Urgent need for defecation}

Representing reports of urgent need for defecation, feelings of incomplete control, and inability to control defecation. Rate according to intensity, frequency, and impact on social performance.

0 - Normal control

1 - Occasional feelings of urgent need for defecation Frequent feelings of urgent need for defecation

2 - with sudden need for a toilet interfering with social performance

3 - Inability to control defecation

\section{Feeling of incomplete evacuation}

Representing reports of defecation with straining and a feeling of incomplete evacuation of stools. Rate according to intensity and frequency.

0 - Feeling of complete evacuation without straining

1 - Defecation somewhat difficult; occasional

1 - feelings of incomplete evacuation

2 - Defecation definitely difficult; often feelings of incomplete evacuation

3 - Defecation extremely difficult; regular feelings of incomplete evacuation

Table 2: Summarizes Gastro intestinal symptom rating scale (7) (GSRS) before and after treatment

\begin{tabular}{|l|c|c|}
\hline Symptoms & $\begin{array}{l}\text { Before } \\
\text { treatment }\end{array}$ & $\begin{array}{l}\text { After } \\
\text { treatment }\end{array}$ \\
\hline Abdominal pain & 2 & 1
\end{tabular}

Heartburn.

$2 \quad 0$

Acid regurgitation

Sucking sensations in the

0

0

epigastrium

Nausea and vomiting

Borborygmus

Abdominal distension

Eructation

Increased flatus

Decreased passage of

stools

Increased passage of

stools

Loose stools

$3 \quad 1$

Hard Stools

Urgent need for defecation

Feeling of incomplete

evacuation

Total

$0 \quad 0$

0

0

\begin{tabular}{l|l}
3 & 0 \\
3 & 1
\end{tabular}

$1 \quad 0$

0

\begin{tabular}{l|l}
2 & 0
\end{tabular}

0

0

$\begin{array}{ll}0 & 0\end{array}$

\begin{tabular}{l|l}
2 & 1
\end{tabular}

0

2

24 


\section{Treatment}

Samana snehapanam (internal oleation therapy) with coconut oil $(25 \mathrm{ml})$ for 15 days. Time of administration of medicine was in morning, on getting appetite. Hot water given as anupana (adjuvant).

\section{Pathya-apathya}

After the digestion of coconut oil she was advised to take kanji on getting appetite. Spicy items were restricted.

\section{Results}

Significant difference was found in all symptoms (Table 1,2). IgG H-Pylori test became negative after trial.

\section{Discussion}

The clinical characters of the patient infected with H-pylori bacteria showed the similarities with parinaamashoola with vatha -pitha predominance. In physiological state kapha protects aamasaya (stomach) from the eroding effects of paacaka pitta. But here the perturbation of kapha occurred in the first stage of pathogenesis itself. Kapha dislodges from its place and pitha along with vaatha causes Shoola (pain) during the period of digestion. According to yoga Yoga ratnakara Dvandaja Parinaamashoola, should be treated with sneha yoga(5). Among ayurvedic Ayurvedic treatises Susrutha samhitha narrates the properties of coconut oil among Taila varga (oil group). Madhura rasa (sweet taste), seetha veerya (cold potency), madhura vipaka, vatha pitha samana, are attributed to it(6). While analyzing the symptoms of patient with H-pylori infestation pain during digestion ,abdominal distention, constipation, borborygymus etc. is are caused by vaatha dosha.coconut oil is vaatha hara due to guru(heavy), snigda (unctuous) , brhmana (nourish) properties. Coconut oil has vaathaanulomana (mild laxative) effect(8).which assist aapana vaayu for its proper function. Burning sensation produced by irritation of kledaka kapha by excess apachaka pitha .pitha samana property of coconut oil helps to reduce it. Moreover coconut oil is shleshmakara,(9) this will helps to nourish the kledakaka kapha in amasaya (stomach). Modern research explains that Coconut oil is predominantly composed of saturated fatty acids with a good percentage of medium-chain fatty acids(10). A large body of evidence now exists to support the role of Helicobacter pylori as the etiologic agent of active chronic gastritis and peptic ulcer disease and as a risk factor for development of gastric carcinoma (11). Medium chain triglycerides shows bactericidal property for $H$. pylori, the gram-negative bacterium associated with chronic superficial gastritis and peptic ulcer disease in humans (12). One of the primary survival mechanisms used by $\mathrm{H}$-pylori against stomach acidity is protection by urease. Medium chain fatty acids affect the bacterium by acidification of its cell cytoplasm (13). The growth of Helicobacter pylori is inhibited by linoleic acid. Linoleic is a component of coconut oil (14)

After snehapaana(oleation therapy) significant improvement is also observed in the subjective paramerters of GSRS scale. So patients with h-pylori infestation can be approached through samana snehapana (oleation therapy) and coconut oil will be a good therapeutic option.

\section{Reference}

1. Anthony S. Fauci et al., Harrison's Principles of Internal Medicine, 19 th $^{\text {edition, New }}$ York, McGraw-Hill education,2015,1915

2. Anthony S. Fauci et al., Harrison's Principles of Internal Medicine, 19th edition, New York, McGrawHill education, 2015,1916

3. Sreekumar T, Ashthanga Hrdayam Suthrasthanam of Vaghbata, 2nd edition, Thrissur, Harisree hospital,1/1/2008,

4. Sreekantha Murthy KR, Madhava nidhana roga vinischaya of Madhavakara, 2nd edition, Varanasi, Chaukhambha Orientalia. 2011,99

5. Madham Shetty Suresh Babu, Yogarathakara of, 1stedition, Varanasi, Chaukhamba Sanskrit Series, 2008, 712

6. Sharma PV, Suśruta saṃhita of Suśruta with the Nibandhasangraha Commentry, Varanasi, Chaukhambha Viswabharati, 2005, 204

7. Jan Svedlund et.al, GSRS-A Clinical rating scale for gastrointestinal symptoms in patients with irritable bowel syndrome and peptic ulcer, digestive diseases and sciences, 2/2/1988, 33(12), 129-134

8. Vaidya Chirayathu Potti, Vaidya Manjari, 1stedition, Palakkad, Sidheswara Publications, 2002, 17

9. Jyothir Mithra, Ashtanga Samgraha of Vridha Vaghbata with Sasilekha commentary, 1st edition, Varanasi, Chaukhamba Sanskrit Series. 2005,44

10. Shijna Kappally et.al, Coconut oil- a review of potential applications, Hygeia journal for drugs and medicine, 2015 Oct, 7(2), 36

11. Christensen. A et.al, clinicians accept the role of Helicobacter pylori in duodenal ulcer disease? A survey of European gastroenterologists and general practitioners, J. Intern. Med, November 1994, 236(5), 501-505

12. Bryonw. Petchow et .al, Susceptibility of Helicobacter pylori to bactericidal Properties of medium chain Monoglycerides and free fatty acids, Anti-microbial agents \& chemo therapy . 1994 Feb, 40(2), 302-306

13. Cynthia Q. Sunet al Antibacterial actions of fatty acids and monoglycerides against Helicobacter pylori, FEMS Immunology and Medical Microbiology, 2003 May, 36(2), 14

14. Thompson, L., Aet.al, Inhibitory effect of polyunsaturated fatty acids on the growth of Helicobacter pylori: a possible explanation of the effect of diet on peptic ulceration. Gut,1994 nov, 35(11), 1559 . 